\title{
Acute Stress Impairs Hippocampal Mossy Fiber-CA3 Long-Term Potentiation by Enhancing cAMP-Specific Phosphodiesterase 4 Activity
}

\author{
Chien-Chung Chen', Chih-Hao Yang', Chiung-Chun Huang ${ }^{2}$ and Kuei-Sen Hsu*, 1,2,3 \\ 'Institute of Basic Medical Sciences, College of Medicine, National Cheng Kung University, Tainan, Taiwan; ${ }^{2}$ Department of Pharmacology, \\ College of Medicine, National Cheng Kung University, Tainan, Taiwan; ${ }^{3}$ Center for Gene Regulation and Signal Transduction Research, National \\ Cheng Kung University, Tainan, Taiwan
}

\begin{abstract}
The mossy fiber synapses onto hippocampal CA3 neurons show unique molecular features and a wide dynamic range of plasticity. Although acute stress has been well recognized to alter bidirectional long-term synaptic plasticity in the hippocampal CAI region and dentate gyrus, it remains unclear whether the same effect may also occur at the mossy fiber-CA3 synapses. Here, we report that hippocampal slices prepared from adult mice that had experienced an acute unpredictable and inescapable restraint tail-shock stress showed a marked impairment of long-term potentiation (LTP) induced by high-frequency stimulation or adenylyl cyclase activator forskolin. This effect was prevented when animals were submitted to bilateral adrenalectomy or given the glucocorticoid receptor antagonist RU38486 before experiencing stress. In contrast, stress has no effect on synaptic potentiation induced by the nonhydrolysable and membrane-permeable cyclic adenosine 5'-monophosphate (cAMP) analog Sp-8-bromo-cAMPS. No obvious differences were observed between control and stressed mice in the basal synaptic transmission, paired-pulse facilitation, or frequency facilitation at the mossy fiber-CA3 synapses. We also found that the inhibitory effect of stress on mossy fiber LTP was obviated by the adenosine $A_{1}$ receptor antagonist 8-cyclopentyl-I,3,-dipropylxanthine, the non-specific phosphodiesterase (PDE) inhibitor 3-isobutylmethylxanthine, and the specific PDE4 inhibitor 4-(3-butoxy-4-methoxyphenyl)methyl-2-imidazolidone. In addition, stress induces a sustained and profound increase in CAMP-specific PDE4 activity. These results suggest that the inhibition of mossy fiber LTP by acute stress treatment seems originating from a corticosterone-induced sustained increase in the PDE4 activity to accelerate the metabolism of CAMP to adenosine, in turn triggering an adenosine $A_{1}$ receptor-mediated impairment of transmitter release machinery.

Neuropsychopharmacology (2010) 35, 1605-1617; doi:10.1038/npp.2010.33; published online 17 March 2010
\end{abstract}

Keywords: stress; long-term potentiation; cAMP; phosphodiesterase; adenosine; mossy fiber

\section{INTRODUCTION}

Stress is known to affect multiple forms of synaptic plasticity and memory processes in the hippocampus (Kim and Yoon, 1998; McEwen, 1999; Garcia, 2001; Kim and Diamond, 2002; Diamond et al, 2004; Huang et al, 2005; Roozendaal et al, 2009). For example, extensive evidence from both in vitro and in vivo electrophysiological studies have shown that a brief experience to an uncontrollable stress can impair high-frequency stimulation (HFS)-induced long-term potentiation (LTP) (Shors et al, 1989; Diamond et al, 1992; Kim et al, 1996; Xu et al, 1997; Yang et al, 2004, 2006), whereas the induction of long-term

*Correspondence: Dr K-S Hsu, Department of Pharmacology, College of Medicine, National Cheng Kung University, No. I, University Road, Tainan City 70।, Taiwan, Tel: + 88662353535 ext: 5498, Fax: + 886 6274 9296, E-mail: richard@mail.ncku.edu.tw

Received 23 October 2009; revised 20 January 2010; accepted 19 February 2010 depression by prolonged low-frequency stimulation is facilitated in the CA1 region of hippocampus (Kim et al, 1996; Xu et al, 1997; Yang et al, 2004, 2005). The dentate gyrus, as well as the CA1 region of the hippocampus, is vulnerable to stress. Depending on its severity and context, stress has been shown to facilitate or impair the induction of LTP in the dentate gyrus (Shors and Dryver, 1994; Korz and Frey, 2003, 2005; Ahmed et al, 2006; Kavushansky et al, 2006).

The mossy fiber synapses between granule cells in the dentate gyrus and pyramidal neurons in the CA3 region are important component of the hippocampal excitatory trisynaptic circuit. These synapses are relatively large in size and express several unique transmission and plastic properties, including low basal release probability, pronounced paired-pulse facilitation (PPF), frequency facilitation, and posttetanic potentiation (Griffith, 1990; Salin et al, 1996; Zucker and Regehr, 2002). Moreover, mossy fiber-CA3 synapses also display a particular form of LTP that is mainly expressed presynaptically and is 
independent of $\mathrm{N}$-methyl-D-aspartate (NMDA) receptor activation (Harris and Cotman, 1986; Zalutsky and Nicoll, 1990; Nicoll and Malenka, 1995). Compelling evidence indicates that mossy fiber LTP is triggered by a tetanusinduced rise in presynaptic intracellular $\mathrm{Ca}^{2+}$ that results in activation of a $\mathrm{Ca}^{2+}$ /calmodulin-activated adenylyl cyclase (Huang et al, 1994; Weisskopf et al, 1994; Nicoll and Malenka, 1995; Nicoll and Schmitz, 2005). This in turn causes an increase in presynaptic cyclic adenosine 5 -monophosphate (cAMP) levels to activate the cAMPdependent protein kinase (PKA), which, through mechanisms perhaps involving the synaptic vesicle protein Rab3A and the active zone constituent $\operatorname{RIM} 1 \alpha$, produces a longlasting enhancement in transmitter release (Castillo et al, 1997; Südhof, 2004).

In contrast to NMDA receptor-dependent LTP expressed at the Schaffer collateral-CA1 and the perforant pathdentate gyrus synapses, it is not known whether acute stress affects the induction of NMDA receptor-independent form of mossy fiber LTP. We have, therefore, examined the effects of acute unpredictable and inescapable restrain tailshock stress on the induction of mossy fiber LTP in mouse hippocampal slices. Here, we provide the first evidence that acute behavior stress can impair the induction of mossy fiber LTP through the activation of glucocorticoid receptors, leading to a sustained increase in the cAMP-specific phosphodiesterase 4 (PDE4) activity to accelerate cAMP degradation and subsequently resulting in an increase in the levels of adenosine, which act on the adenosine $A_{1}$ receptors to counteract the enhancement of transmitter release in response to LTP-induction protocol.

\section{MATERIALS AND METHODS}

\section{Animals and Handling}

Healthy adult male C57BL/6 mice (8-12 weeks old) were used in these experiments. All experimental procedures were conducted in adherence to the National Institutes of Health Guide for the Care and Use of Laboratory Animals and were approved by the Institutional Animal Care and Use Committee of National Cheng Kung University. Three to four mice were housed per cage under the conditions of a $12 \mathrm{~h}$ light/dark cycle (lights on from 0600 to 1800 hours) and ad libitum access to food and water. Animals were habituated to the manipulation, that is transporting them to the experimental room, removing them from their cages, handling, and returning them to their home cages. These procedures were repeated twice daily for seven consecutive days before the experiments to minimize the handling stress response. All experiments were conducted during the light phase of the cycle. All efforts were made to minimize animal suffering and to use only the number of animals necessary to produce reliable scientific data.

\section{Adrenalectomy and Corticosterone Replacement}

Adrenalectomy (ADX) was performed through small bilateral dorsal flank incisions under isoflurane anesthesia, using aseptic conditions. ADX mice received replacement corticosterone $(10 \mu \mathrm{g} / \mathrm{ml})$ in drinking water containing $0.9 \%$ saline immediately after surgery. Mice were used in stress experiments 21 days after surgery. Control mice underwent the same surgical procedure as the ADX mice, except that the adrenal glands were not removed (Sham group). The Sham groups were given normal drinking water.

\section{Stress Protocol}

Behavioral stress was evoked by 90 tail shocks ( $1 \mathrm{~mA}$ for $1 \mathrm{~s}$, 30-90 s apart), while restrained in a Plexiglas tube as described earlier (Yang et al, 2004). This restraint-tail-shock stress protocol, adapted from the 'learned helplessness' paradigm (ie, animals are exposed to an unpredictable and uncontrollable aversive stimulus) (Seligman and Maier, 1967), has been shown earlier to reliably induce behavioral (freezing immobility, piloerection, urination, and defecation) and endocrine (elevated serum corticosterone levels) signs of stress (Kim et al, 1996; Yang et al, 2004). As the stressed mice were unable to reach the food and water, control mice were housed individually in their home cages and were deprived of food and water for a period of $90 \mathrm{~min}$ before killing.

\section{Plasma Corticosterone Assay}

Blood samples were obtained from the tail just before and immediately after stress, centrifuged at $1000 \mathrm{~g}$ and plasma was separated and stored at $-20^{\circ} \mathrm{C}$. Plasma corticosterone levels were determined using a commercially available enzyme immunoassay (EIA) kit (Cayman Chemical, Ann Arbor, MI) according to the manufacturer's instructions. All assays were carried out in duplicate. The detection limit was $24 \mathrm{pg} / \mathrm{ml}$. Intra- and inter-assay variations were 4.1 and $9.5 \%$, respectively.

\section{Electrophysiology}

Immediately after stress, mice were anesthetized deeply with halothane, decapitated, the hippocampi were rapidly removed, and $400 \mu \mathrm{m}$ transverse slices were prepared using a Leica VT1200S vibrating tissue slicer (Leica, Nussloch, Germany). Slices were collected from the $2 \mathrm{~mm}$ dorsal (septal) pole of the hippocampus. After their preparation, slices were placed in a holding chamber of artificial cerebrospinal fluid (aCSF) oxygenated with 95\% $\mathrm{O}_{2}-5 \% \mathrm{CO}_{2}$ and kept at room temperature for at least $1 \mathrm{~h}$ before recording. The aCSF solution was composed of the following (in $\mathrm{mM}$ ): $117 \mathrm{NaCl}, 4.7 \mathrm{KCl}, 2.5 \mathrm{CaCl}_{2}, 1.2$ $\mathrm{MgCl}_{2}, 25 \mathrm{NaHCO}_{3}, 1.2 \mathrm{NaH}_{2} \mathrm{PO}_{4}$, and 11 glucose at $\mathrm{pH}$ 7.3-7.4.

For extracellular recordings, a single slice was transferred to a submerge-type recording chamber, maintained at $32.0 \pm 0.5^{\circ} \mathrm{C}$, and continually superfused with ACSF solution at a rate of $2-3 \mathrm{ml} / \mathrm{min}$. A bipolar stainless steel-stimulating electrode was placed in the granule cell layer of the dentate gyrus to activate mossy fiber afferents at $0.033 \mathrm{~Hz}$. The intensity used for stimulation was set to produce $\sim 30 \%$ of the maximum response. Mossy fiber field excitatory postsynaptic potentials (fEPSPs) were recorded in the stratum lucidum of the CA3 region of the hippocampus using a glass microelectrode filled with $1 \mathrm{M} \mathrm{NaCl}$ (resistance of 2-3 M $\Omega$ ) as described earlier (Huang et al, 2002). The 
extent of the stratum lucidum was delineated by moving the recording microelectrode in a direction perpendicular to the CA3 pyramidal cell layer until a reversal of mossy fiber fEPSPs could be observed. As the synaptic response to mossy fiber stimulation could be contaminated responses activated by disynaptic activation of associational collateral fibers and/or association axon reflex inputs (Weisskopf and Nicoll, 1995), the following three procedures were performed to minimize the contribution of fibers other than mossy fibers to the fEPSPs as described earlier (Zalutsky and Nicoll, 1990; Chen et al, 2001). First, the stimulating electrode was placed at a site in the granule cell layer of the dentate gyrus in which stimulation of the CA3 stratum lucidum produced the maximal antidromic field potential. Second, the reversal of the waveform as the recording microelectrode was moved from the stratum lucidum to the stratum radiatum served to define mossy fiber inputs. Third, positivities after the mossy fiber fEPSP were minimized, as these may reflect contamination by disynaptic excitatory inputs. Mossy fiber synaptic responses were characterized by fast rise times and by the large-frequency facilitation that occurred when stimulation frequency were changed from 0.033 to $1 \mathrm{~Hz}$ (Salin et al, 1996). Experiments were included for data analysis only if $\left(2 S, 2^{\prime} R, 3^{\prime} R\right)-2-\left(2^{\prime}, 3^{\prime}-\right.$ dicarboxycyclopropyl)glycine (DCG-IV; $0.5 \mu \mathrm{M}$ ), the potent group II metabotropic glutamate receptor agonist that selectively blocks mossy fiber responses, caused a $>80 \%$ reduction in the fEPSPs (Castillo et al, 1997). In all experiments, baseline synaptic transmission was monitored for $30 \mathrm{~min}$ before delivering HFS. The strength of synaptic transmission was quantified by measuring the amplitude of fEPSPs. The fEPSP amplitude was calculated after subtracting the mossy fiber volley from the evoked response. The mossy fiber volley was recorded at the end of experiment after blocking synaptic transmission with 6-cyano-7-nitroquinoxaline-2,3-dione (CNQX; $20 \mu \mathrm{M})$ and D-2-amino-5phosphonovalerate (D-APV, $50 \mu \mathrm{M}$ ). PPF was assessed by using a succession of paired pulses separated by intervals of $20,40,60,80,100,150$, and $200 \mathrm{~ms}$ at baseline stimulation intensity. LTP was induced by applying two trains of HFS $(100 \mathrm{~Hz}, 1 \mathrm{~s}$ duration at test stimulation strength) delivered with an interval of $20 \mathrm{~s}$. D-APV $(50 \mu \mathrm{M})$ was present for the duration of all experiments to block LTP at the CA3 recurrent collateral synapses. The levels of synaptic potentiation reported here were calculated as the changes in fEPSP amplitude measured 50 min after HFS. Microelectrodes were pulled from microfiber 1.0-mm capillary tubing on a Brown-Flaming electrode puller (Sutter Instruments, San Rafael, CA). Electrical signals were collected with an Axoclamp-2B (Axon Instruments, Union City, CA) filtered at $2 \mathrm{kHz}$ and sampled at $5-10 \mathrm{kHz}$, and an Intel Pentiumbased computer with pCLAMP software (Version 7.0, Axon Instruments) was used for data acquisition and analysis. The experiments were performed with the experimenter blind to the status of the animals from which slices were prepared.

\section{Preparation of Synaptosomes}

Immediately after stress, mice were anesthetized deeply with halothane, decapitated, and the synaptosomal fractions were prepared from the CA3 region of hippocampal slices as described elsewhere with some modifications (Ortiz et al, 1995; Yang et al, 2005). In brief, the microdissected subregions were homogenized in $0.32 \mathrm{M}$ sucrose, $1 \mathrm{mM}$ EDTA, $4 \mathrm{mM}$ Tris and $10 \mathrm{mM}$ glucose, $\mathrm{pH}$ 7.4, using a glassTeflon homogenizer. Homogenates were centrifuged at $1000 \mathrm{~g}$ for $10 \mathrm{~min}\left(4^{\circ} \mathrm{C}\right)$. The resultant pellet was discarded, and the supernatant was spun at $9000 \mathrm{~g}$ for $10 \mathrm{~min}$ in a microcentrifuge $\left(4^{\circ} \mathrm{C}\right)$. The pellets constituted the crude synaptosomal fraction. The crude synaptosomal fractions were resuspended in Krebs-Ringer buffer (KRB) (in mM: $\mathrm{NaCl}, 120 ; \mathrm{KCl}, 4.7 ; \mathrm{CaCl}_{2}, 2.2 ; \mathrm{MgCl}_{2}, 1.2$; HEPES, 25; $\mathrm{MgSO}_{4}, 1.2 ; \mathrm{KH}_{2} \mathrm{PO}_{4}, 1.2$; glucose, 10 ; and $\mathrm{pH}$ 7.4). The protein contents were determined by using a Pierce BCA Protein Assay kit (Thermo Scientific, Rockford, IL).

\section{cAMP Assay}

After the synaptosomes ( $\sim 1 \mathrm{mg}$ of protein) were incubated with $1 \mathrm{ml}$ of oxygenated $\mathrm{KRB}$ at $37^{\circ} \mathrm{C}$ for $30 \mathrm{~min}$, the medium was changed to $0.3 \mathrm{ml} \mathrm{KRB}$ containing forskolin or 4-(3-butoxy-4-methoxyphenyl)methyl-2-imidazolidone (Ro 20-1724) medium. After the incubation at $37^{\circ} \mathrm{C}$ for $5 \mathrm{~min}$, the reaction was terminated by addition of $5 \%$ ice-cold trichloroacetic acid. After homogenization, centrifugation, extraction of trichloroacetic acid by water-saturated diethylether, and acetylation, the levels of cAMP accumulation in synaptosomes was determined using a cAMP Complete EIA kit (Assay Designs, Ann Arbor, MI) according to the manufacturer's instructions. The detection limit was $0.039 \mathrm{pmol} / \mathrm{ml}$.

\section{PDE Activity Assay}

PDE activity was assayed using a Cyclic Nucleotide PDE Assay kit (BIOMOL International, Plymouth Meeting, PA) according to the manufacturer's instructions. The CA3 region of the hippocampal slice was transferred into ice-cold lysis buffer $(50 \mathrm{mM}$ Tris- $\mathrm{HCl}, 100 \mathrm{mM} \mathrm{NaCl}$, $15 \mathrm{mM}$ sodium pyrophosphate, $50 \mathrm{mM}$ sodium fluoride, $1 \mathrm{mM}$ sodium orthovanadate, $5 \mathrm{mM}$ EGTA, $5 \mathrm{mM}$ EDTA, $1 \mathrm{mM}$ phenylmethylsulfonyl fluoride, $1 \mu \mathrm{M}$ microcystin-LR, $1 \mu \mathrm{M}$ okadaic acid, $0.5 \%$ Triton X-100, $2 \mathrm{mM}$ benzamidine, $60 \mu \mathrm{g} / \mathrm{ml}$ aprotinin, and $60 \mu \mathrm{g} / \mathrm{ml}$ leupeptin, $\mathrm{pH} 7.4)$ and ground with a pellet pestle (Kontes glassware, Vineland, $\mathrm{NJ})$. Samples were sonicated and spun down at $15000 \mathrm{~g}$ at $4^{\circ} \mathrm{C}$ for $10 \mathrm{~min}$. Twenty-microliter supernatants of each sample were dispensed into 96-well microtiter plate and incubated with the assay reagents at $30^{\circ} \mathrm{C}$ for $30 \mathrm{~min}$ with mild shaking. The absorbances of all samples were measured at $620 \mathrm{~nm}$ using a Molecular Devices Spectramax Microplate Reader (Molecular Devices, Foster City, CA). PDE activity was calculated using an equation obtained from the linear regression fit of the 5'-AMP standard curve. All assays were run in duplicate. The PDE4 activity was determined by subtracting non-PDE4 activity (in the presence of $30 \mu \mathrm{M}$ rolipram) from total PDE activity. Enzyme activity was expressed in picromole cAMP hydrolyzed per minute per microgram of protein. Protein concentrations were determined using Bio-Rad Bradford Protein Assay kit (Hercules, CA). 


\section{Drug Treatment}

RU28318 $(10 \mathrm{mg} / \mathrm{kg})$ or RU38486 $(40 \mathrm{mg} / \mathrm{kg})$ was administered $30 \mathrm{~min}$ before stress by intraperitoneal injection, which has earlier been shown to effectively block the mineralocorticoid or glucocorticoid receptor functions, respectively (Kim et al, 1998; Saal et al, 2003; Yuen et al, 2009). As $10 \mathrm{mg} / \mathrm{kg}$ RU28318 has been reported to produce greater occupancy of mineralocorticoid receptors $(\sim 60 \%)$ without affecting glucocorticoid receptor binding (Kim et al, 1998), we, therefore, used this dose to evaluate the function of mineralocorticoid receptors in mediating stress effect. Control animals were injected with the vehicle propylene glycol for RU38486 and RU28318. In the in vitro slice experiments, all drugs were applied by dissolving them to the desired final concentrations in the aCSF and by switching the perfusion from control ACSF to drugcontaining aCSF. Appropriate stock solutions of drugs were made and diluted with aCSF just before application. Forskolin, 3-isobutyl-methylxanthine (IBMX), 8-cyclopentyl-1,3-dipropylxanthine (DPCPX), 4-(3-butoxy-4-methoxyphenyl)methyl-2-imidazolidone (Ro 20-1724), and rolipram were dissolved in dimethylsulfoxide (DMSO) stock solution and stored at $-20^{\circ} \mathrm{C}$ until the day of experiment. The concentration of DMSO in the perfusing medium was $0.1 \%$, which alone had no effect on the basal mossy fiber synaptic transmission (Chen et al, 2001). $N^{6}$-cyclopentyladenosine (CPA) was prepared by first dissolving it in an equimolar amount of $\mathrm{HCl}$ as a concentrated stock and then diluting to its final concentration in aCSF. Other drugs used in this study were dissolved in distilled water. Forskolin, Ro 20-1724, DPCPX, rolipram, CNQX, D-APV, and DCG-IV were purchased from Tocris Cookson (Bristol, UK); CPA and IBMX were obtained from Sigma (St Louis, MO); Sp-8-bromo-adenosine 3', 5'-monophosphorothioate (Sp-8-bromo-cAMPS) was purchased from Calbiochem (La Jolla, CA).

\section{Data Analysis}

All data are expressed as mean \pm SEM. Number of animals used is indicated by $n$. The significance of the difference between the mean was calculated by paired or unpaired Student's $t$-test with SigmaStat software version 2.0 (SPSS, Chicago, IL). Comparison of the cumulative probability distributions for the LTP amplitude was performed using the non-parametric Kolmogorov-Smirnov test (Figure 2b). Probability values of $p<0.05$ were considered to represent significant differences.

\section{RESULTS}

\section{Effect of Stress on Mossy Fiber Synaptic Transmission and Frequency Facilitation}

We earlier used restraint-tail-shock exposure to activate hypothalamus-pituitary-adrenal (HPA) axis response in rats and elicit an impairment of NMDA receptor-dependent LTP in the hippocampal CA1 region (Yang et al, 2004). To determine whether such a behavioral stress protocol exerts a similar effect in mice, we examined changes in plasma corticosterone response to stress. In response to $90 \mathrm{~min}$ stress, significantly higher levels of plasma corticosterone $(289.6 \pm 22.5$ vs $36.9 \pm 8.9 \mathrm{ng} / \mathrm{ml}$ in basal condition, $n=12$; $p<0.05$, paired Student's $t$-test) were observed, confirming that our stressor could effectively activate HPA response in mice.

We next examined the effects of stress on the properties of synaptic transmission and plasticity at the mossy fiberCA3 synapses. To determine whether the basal synaptic transmission at the mossy fiber-CA3 synapses was altered by stress, stimulus-response relationships for extracellular fEPSP obtained from control and stressed mouse slices were compared. The input-output curves were generated by plotting the fEPSP amplitude $v s$ the presynaptic fiber volley amplitude. Analysis of evoked fEPSPs revealed no significant differences in input-output curves, maximal responses, and fEPSP waveform in slices from stressed and control mice (Figure 1a).

To determine whether stress alters the presynaptic function, we examined PPF, a transient form of presynaptic plasticity in which the second of two closely spaced stimuli elicits enhanced transmitter release (Zucker, 1989). As shown in Figure 1b, pairs of presynaptic fiber stimulation pulses delivered over an interpulse interval range of 20$200 \mathrm{~ms}$ evoked nearly identical amounts of PPF in slices from stressed and control mice at all intervals.

Mossy fiber-CA3 synapses display a large short-term frequency facilitation that occurs when the frequencies of repetitive stimulation are increased (Salin et al, 1996). We also compared the induction of frequency facilitation in slices from stressed and control mice in experiments in which the stimulus frequency was increased from 0.033 to $1 \mathrm{~Hz}$. As shown in Figure $1 \mathrm{c}$, the facilitation rapidly reached a maximum level of $\sim 400 \%$ and stabilized at this level until stimulation ceased. The extent of the facilitation was not significantly different in slices from stressed and control mice.

\section{Stress Impairs Mossy Fiber LTP}

We then examined the effect of stress on the induction of NMDA receptor-independent mossy fiber LTP. The LTP was induced by two $1 \mathrm{~s}$ trains of $100 \mathrm{~Hz}$ stimuli separated by intertrain interval of $20 \mathrm{~s}$ in the presence of D-APV $(50 \mu \mathrm{M})$ to minimize the possible contamination by NMDA receptordependent LTP. In slices from control mice, this protocol induced a robust LTP, whereas in slices from stressed mice, LTP was significantly impaired (50 min after HFS: control, $170.8 \pm 6.5 \%$ of baseline, $n=8$; stressed, $130.4 \pm 9.8 \%$ of baseline, $n=8 ; p<0.05$ ) (Figure $2 \mathrm{a}$ and $\mathrm{b}$ ), suggesting that stress impairs the induction of mossy fiber LTP. However, the level of posttetanic potentiation was not significantly different in slices from stressed and control mice. Together, these results suggest that acute stress specifically alters long-term, but not short-term plasticity at the mossy fiberCA3 synapses.

Might the effect of stress on the mossy fiber LTP result from the release of corticosterone acting on the corticosteroid receptors? The hippocampus contains an abundance of two types of corticosteroid receptors: mineralocorticoid and glucocorticoid receptors (Jacobson and Sapolsky, 1991). To assay the function of glucocorticoid receptor activation in mediating the effect of stress on LTP, the specific 
a
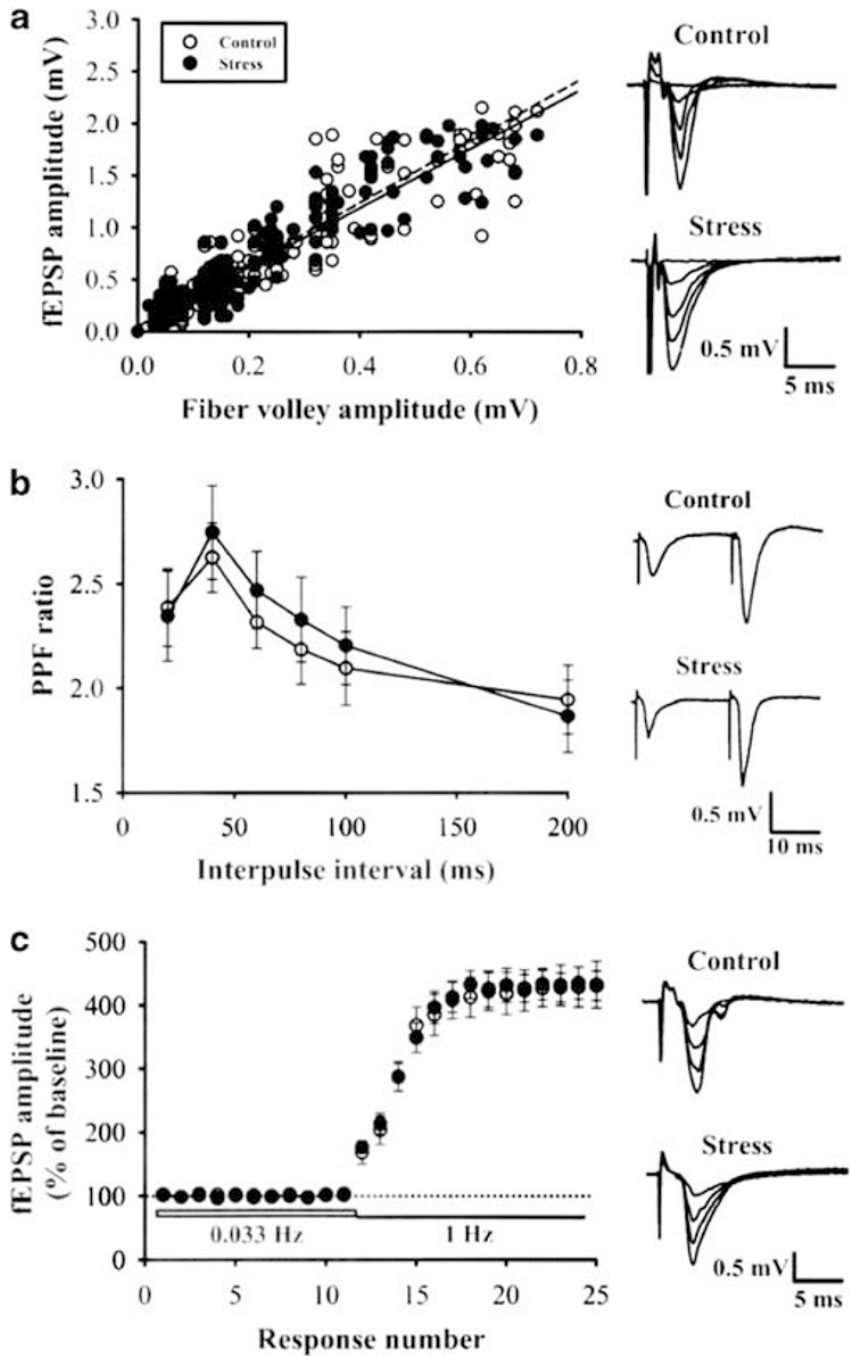

Figure I Basal properties of synaptic transmission are unaltered by acute stress. (a) Input-output curves constructed from the fEPSP amplitude vs the fiber volley amplitude measured at increasing stimulation intensities at the mossy fiber-CA3 synapses of hippocampal slices from control $(n=8$; open symbols) and stressed ( $n=8$; filled symbols) mice. The superimposed fEPSPs on the right illustrate respective recordings from example experiments. (b) Comparison of PPF ratio in slices from control $(n=5$; open symbols) and stressed ( $n=5$; filled symbols) mice. The plot summarizes facilitation of the second fEPSP amplitude relative to the first one as a function of the interpulse interval. The fEPSPs on the right illustrate respective recordings from example experiments to paired-pulse stimulation with an interpulse interval of $20 \mathrm{~ms}$. (c) Frequency facilitation measured at I Hz stimulation was not significantly changed in slices from stressed mice $(n=5$; filled symbols) when compared with control mice $(n=5$; open symbols). Horizontal bars denote the period of the delivery of a series of stimulation at a frequency of 0.033 or $1 \mathrm{~Hz}$. The superimposed fEPSPs on the right illustrate respective recordings from example experiments during $\mathrm{I} \mathrm{Hz}$ stimulation. Error bars indicate SEM.

glucocorticoid receptor antagonist, RU38486 (40 mg/kg), was intraperitoneally injected $30 \mathrm{~min}$ before stress. As shown in Figure 3a and b, administration of RU38486 almost completely prevented the stress-induced impairment of LTP. When LTP was assessed at 50 min after HFS, slices from stressed mice injected with vehicle propylene glycerol exhibited impaired LTP $(128.5 \pm 11.6 \%$ of baseline, $n=6)$ in comparison with slices from control mice injected with
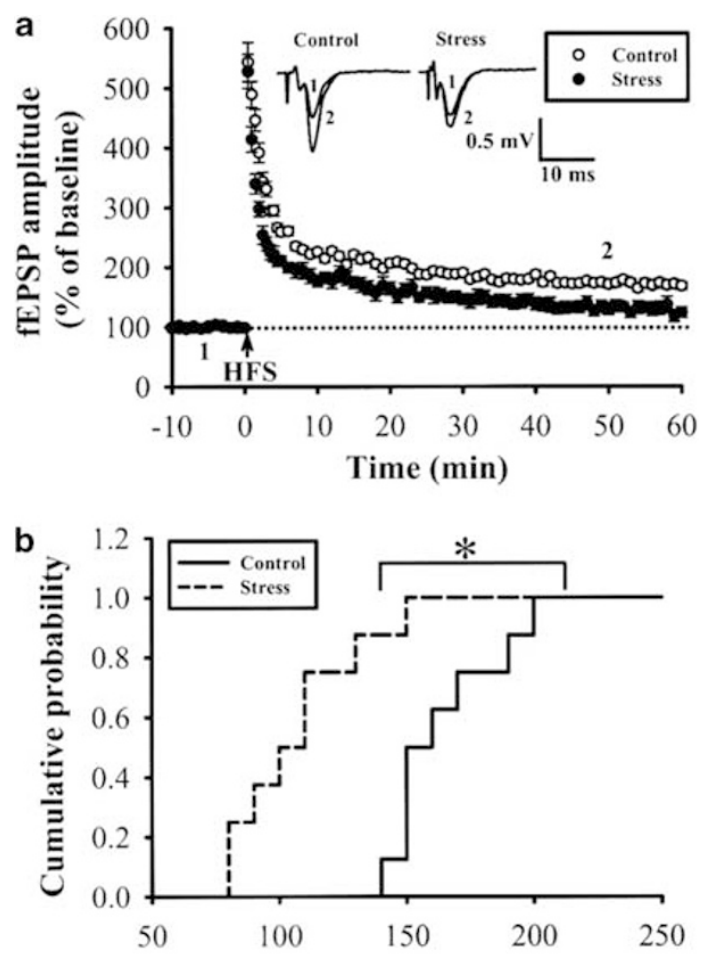

fEPSP amplitude ( $\%$ of baseline)

Figure 2 Stress impairs subsequent LTP induction at the mossy fiberCA3 synapses. (a) LTP elicited by two trains of $100 \mathrm{~Hz}$ stimuli (HFS) with I s duration separated by $20 \mathrm{~s}$ intertrain interval in the presence D-APV $(50 \mu \mathrm{M})$. The slices from stressed mice $(n=8$; filled symbols) displayed a deficit in LTP when compared with those from control mice $(n=8$; open symbols). (b) Cumulative probability plot showing the distribution of the LTP magnitude, as determined by the mean fEPSP amplitude (normalized to the average baseline value of each slice) at 50 min after HFS for the dataset shown in (a). The superimposed fEPSPs in the inset illustrate respective recordings from example experiments taken at the time indicated by number. The dash lines show level of baseline. Error bars indicate SEM. $* p<0.05$ Kolmogorov-Smirnov test.

vehicle (178.6 $\pm 12.8 \%$ of baseline, $n=6)$, slices from control mice injected with RU38486 (175.6 $\pm 12.3 \%$ of baseline, $n=4$ ), and slices from stressed mice injected with RU38486 (180.3 $\pm 8.7 \%$ of baseline, $n=6 ; p<0.05$ when compared with the slices from stressed mice injected with vehicle). In contrast, prior administration of specific mineralocorticoid receptor antagonist RU28318 $(10 \mathrm{mg} / \mathrm{kg})$ did not affect the stress effect $(136.7 \pm 9.1 \%$ of baseline, $n=6 ; p>0.05$ when compared with the slices from stressed mice injected with vehicle). Administration of RU28318 alone also had no significant effect on the induction of LTP in control mice $(182.5 \pm 8.7 \%$ of baseline, $n=4)$. These results support the hypothesis that stress impairs mossy fiber LTP mainly through the corticosterone release to activate glucocorticoid receptors.

To explore further the importance of corticosterone to mediate the effect of stress on mossy fiber LTP, we next performed the same experiments in bilateral ADX mice. As shown in Figure 3c and d, the inhibitory effect of stress on mossy fiber LTP was prevented by ADX. When LTP was assessed at 50 min after HFS, slices from ADX stressed mice showed normal LTP $(178.3 \pm 8.6 \%$ of baseline, $n=5)$ in comparison with slices from ADX control mice 

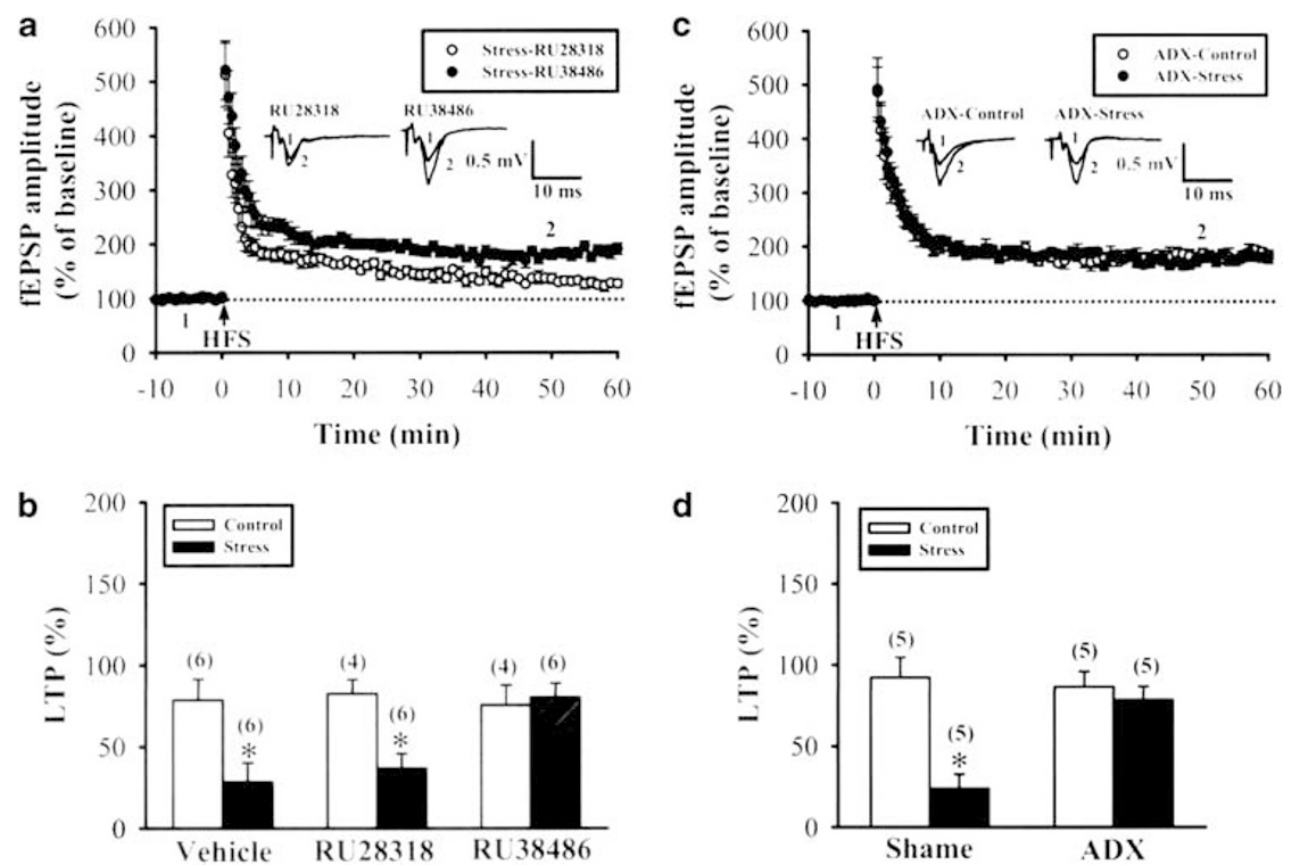

Figure 3 Activation of glucocorticoid receptors mediates the impairment of mossy fiber LTP by acute stress. (a, b) Summary of experiments shows that in slices from stressed mice intraperitoneally injected with glucocorticoid receptor antagonist RU38486 (40 mg/kg) 30 min before stress exposure, two I-s trains of $100 \mathrm{~Hz}$ stimuli induced a reliable LTP that was not significantly different from that observed in slices from the control mice that received vehicle or RU38486 only. In contrast, prior administration of specific mineralocorticoid receptor antagonist RU283 I 8 ( $10 \mathrm{mg} / \mathrm{kg}$ ) did not affect the inhibitory effect of stress on LTP induction. (c, d) Summary of experiments shows that stress-induced impairment of LTP was absent in slices from ADX mice when compared with sham-operated mice. The superimposed fEPSPs in the inset illustrate respective recordings from example experiments taken at the time indicated by number. The dash lines show level of baseline. The number in the parenthesis represents the number of animal used. Error bars indicate SEM. $* p<0.05$ compared with control mice using unpaired Student's t-test.

$(186.5 \pm 9.5 \%$ of baseline, $n=5)$ and slices from shamoperated control mice $(192.3 \pm 12.3 \%$ of baseline, $n=5)$. In contrast, the sham-operated stressed mice exhibited an impairment of LTP $(123.8 \pm 8.9 \%$ of baseline, $n=5)$. The success of the ADX surgery was confirmed by measuring plasma corticosterone response to stress. ADX significantly reduced both basal $(5.8 \pm 2.8 \mathrm{ng} / \mathrm{ml}, n=10)$ and stressinduced $(11.2 \pm 4.7 \mathrm{ng} / \mathrm{ml}, n=5)$ plasma levels of corticosterone when compared with sham-operated groups (basal condition: $32.8 \pm 7.4 \mathrm{ng} / \mathrm{ml}, n=10$; stress-induced condition: $249.2 \pm 35.8 \mathrm{ng} / \mathrm{ml}, n=5$ ).

\section{Putative Mechanisms of the Effect of Stress on Mossy Fiber LTP}

Having confirmed a function of glucocorticoid receptor activation in mediating the effect of stress on LTP, we next identify the possible signaling components that couple the glucocorticoid receptor activation to exert stress effect. As a rise in presynaptic cAMP is an important component of mossy fiber LTP (Huang et al, 1994; Weisskopf et al, 1994), we explored the possibility that a glucocorticoid receptormediated decrease in cAMP level in mossy fiber nerve terminals is essential for stress-induced impairment of LTP. To explore this possibility, we first examined the effect of stress on the development of LTP by applying the adenylyl cyclases activator forskolin. When forskolin $(25 \mu \mathrm{M})$ was bath applied for $5 \mathrm{~min}$, the amplitude of fEPSP rapidly increased and remained potentiated after washing out forskolin. In slices from control mice, forskolin induced a robust potentiation ( $50 \mathrm{~min}$ after washout of forskolin: $215.3 \pm 12.2 \%$ of baseline, $n=6$ ), whereas slices from stressed mice showed substantially reduced synaptic potentiation $(145.3 \pm 13.5 \%$ of baseline, $n=6 ; p<0.05)$ (Figure 4a). A decrease in the amount of forskolin-induced LTP could be due to an impairment of downstream effectors of cAMP that mediate synaptic potentiation. We tested this prediction by applying a non-hydrolysable and membranepermeable cAMP analog Sp-8-bromo-cAMPs to the slices, a manipulation which could keep PKA activity constant by clamping the cAMP concentration (Tzounopoulos et al, 1998). In contrast to forskolin-induced LTP, we found that bath application of Sp-8-bromo-cAMPs $(100 \mu \mathrm{M})$ for $20 \mathrm{~min}$ induced a similar synaptic potentiation in slices from stressed and control mice (Figure 4b). Average fEPSP amplitude measured $50 \mathrm{~min}$ after washout of Sp-8-bromocAMPs was to $154.5 \pm 9.3 \%$ of baseline $(n=5)$ in slices from stressed mice, which was not significantly different from that of synaptic potentiation recorded in slices from control mice (158.2 $\pm 12.4 \%$ of baseline; $n=5)$. These data indicate that the inhibitory effect of stress on mossy fiber LTP is unlikely due to the inability of the downstream effectors of cAMP to induce synaptic potentiation.

As there is good electrophysiological evidence that adenosine by activating adenosine $A_{1}$ receptors can mask forskolin-induced LTP (Lu and Gean, 1999), we explored the possibility that a facilitation of cAMP metabolism to AMP and hence to adenosine may contribute to stressinduced impairment of LTP. When forskolin was applied in the presence of adenosine $A_{1}$ receptor antagonist DPCPX 

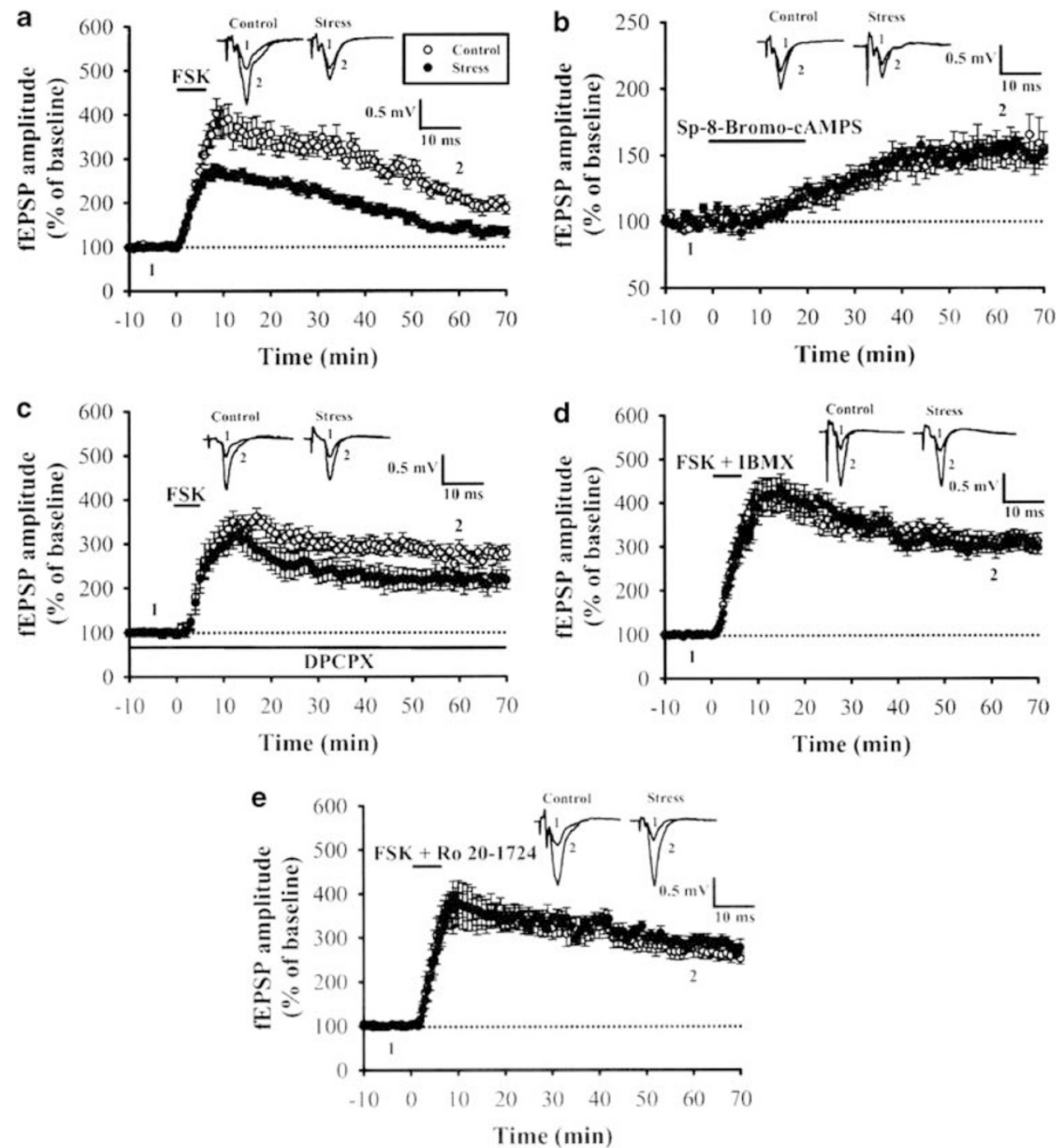

Figure 4 Stress impairs forskolin-induced LTP at the mossy fiber-CA3 synapses. (a) Summary of experiments shows that the slices from stressed mice displayed a deficit in forskolin (FSK, $25 \mu \mathrm{M}$ )-induced LTP ( $n=6$; filled symbols) when compared with those from control mice ( $n=6$; open symbols). (b) Summary of experiments shows that the slices from stressed mice displayed a normal Sp-8-bromo-cAMPs ( $00 \mu M)$-induced LTP ( $n=5$; filled symbols) when compared with those from control mice $(n=5$; open symbols). (c) Summary of experiments shows that the slices from stressed mice displayed a normal forskolin-induced LTP $\left(n=6\right.$; filled symbols) in the presence of adenosine $A_{1}$ receptor antagonist DPCPX $(I \mu M)$ when compared with those from control mice $(n=8$; open symbols). (d) Summary of experiments shows that co-application of forskolin $(25 \mu M)$ and IBMX (500 $\mu$ M) led to a similar LTP in slices from stressed ( $n=5$; filled symbols) and control mice $(n=5$; open symbols). (e) Summary of experiments shows that co-application of forskolin ( $25 \mu M)$ and Ro 20-I724 (200 $\mu$ M) led to a similar LTP in slices from stressed $(n=6$; filled symbols) and control mice $(n=4$; open symbols). Horizontal bars denote the period of delivery of drugs. The superimposed fEPSPs in the inset illustrate respective recordings from example experiments taken at the time indicated by number. Dash lines show level of baseline. Error bars indicate SEM.

$(1 \mu \mathrm{M})$ (Fredholm and Dunwiddie, 1988), the synaptic potentiation induced by forskolin $(25 \mu \mathrm{M})$ became more pronounced and sustained (Figure 4c). The magnitude of synaptic potentiation measured $50 \mathrm{~min}$ after washout of forskolin was similar in slices from stressed $(228.2 \pm 26.5 \%$ of baseline, $n=6 ; p=0.07)$ and control mice $(289.8 \pm 18.5 \%$ of baseline, $n=8$ ). Although application of DPCPX alone induced a significant increase in the fEPSP amplitude, no significant difference was detected in the magnitude of enhancement in slices from stressed $(124.8 \pm 5.2 \%$ of baseline, $n=5)$ and control mice (116.8 $\pm 4.5 \%$ of baseline, $n=5$ ) (Supplementary Figure S1a). These results suggest that the inhibitory effect of stress on forskolin-induced LTP is mediated at least partly through an adenosine $A_{1}$ receptors-dependent mechanism.

To determine whether an increase in cAMP metabolism could account for the decreased forskolin-induced LTP observed in slices from stressed mice, we have compared the magnitude of forskolin-induced LTP in the presence of a non-specific PDE inhibitor IBMX in slices from stressed and control mice. Co-application of forskolin $(25 \mu \mathrm{M})$ and IBMX $(500 \mu \mathrm{M})$ led to a pronounced potentiation of fEPSPs in slices from stressed and control mice (Figure 4d). The magnitude of synaptic potentiation measured $50 \mathrm{~min}$ after washout of forskolin/IBMX was similar in slices from stressed (302.8 $\pm 16.5 \%$ of baseline, $n=5)$ and control mice 
(318.2 $\pm 15.2 \%$ of baseline, $n=5)$. Application of IBMX $(500 \mu \mathrm{M})$ alone for $5 \mathrm{~min}$ also caused a significant increase in the fEPSP amplitude, whereas there was no significant difference in the amount of synaptic enhancement between the slices from stressed (117.3 $\pm 12.7 \%$ of baseline, $n=4)$ and control mice $(114.5 \pm 11.5 \%$ of baseline, $n=4)$, measured $50 \mathrm{~min}$ after washout of IBMX (Supplementary Figure S1b).

Given that IBMX has dual activity, acting as a PDE inhibitor as well as a competitive adenosine receptor antagonist (Bruns et al, 1986; Coffin and Spealman, 1989), we, therefore, performed a similar experiment using Ro 201724, a selective inhibitor of PDE4, which is the predominant PDE expressed in the hippocampus (McPhee et al, 2001). As shown in Figure 4e, there was no significant difference in the magnitude of forskolin $(25 \mu \mathrm{M}) /$ Ro $20-1724$ $(200 \mu \mathrm{M})$-induced LTP measured $50 \mathrm{~min}$ after washout of forskolin/Ro 20-1724 in slices from stressed $(295.5 \pm 14.5 \%$ of baseline, $n=6)$ and control mice $(276.5 \pm 22.9 \%$ of baseline, $n=4$ ). Although application of Ro 20-1724 alone for $5 \mathrm{~min}$ induced a significant increase in the fEPSP amplitude, no significant difference was observed in the magnitude of enhancement in slices from stressed $(108.6 \pm 5.3 \%$ of baseline, $n=4)$ and control mice $(106.5 \pm 4.5 \%$ of baseline, $n=4)$, measured $50 \mathrm{~min}$ after washout of Ro 20-1724 (Supplementary Figure S1c).

As a further test of whether the responsiveness of adenosine $A_{1}$ receptors to adenosine was changed after stress, the effect of the selective and metabolically stable adenosine $A_{1}$ receptor agonist CPA on the fEPSPs was examined. The dose-response curve for CAP to inhibit fEPSPs was the same in slices from stressed and control mice (Supplementary Figure S2), excluding a change in the sensitivity of adenosine $A_{1}$ receptors to adenosine as a possible explanation for the effect of stress on mossy fiber LTP.

Next, we asked whether blockade of adenosine $A_{1}$ receptors or PDE4 activity is sufficient to rescue the stress-induced impairment of LTP with HFS protocol. We found that, in the presence of DPCPX $(1 \mu \mathrm{M})$, HFS normally induced LTP in slices from stressed mice $(193.6 \pm 13.2 \%$ of baseline, $n=4)$ to a similar extent as those observed for control mice (201.2 $\pm 12.8 \%$ of baseline, $n=4$ ) (Figure 5a and c). In addition, when LTP was induced in the presence of Ro 20-1724 $(200 \mu \mathrm{M})$, slices from stressed rats exhibited normal LTP (196.2 $\pm 7.5 \%$ of baseline, $n=6)$ in comparison with slices from control mice $(211.5 \pm 11.6 \%$ of baseline, $n=6$ ) (Figure $5 \mathrm{~b}$ and $\mathrm{c}$ ). Although long-term application of Ro 20-1724 alone caused a significant increase in the fEPSP amplitude, no significant difference was detected in the magnitude of enhancement in slices from stressed $(128.5 \pm 6.5 \%$ of baseline, $n=4)$ and control mice $(122.1 \pm 5.3 \%$ of baseline, $n=4$ ) (Supplementary Figure S1d).

\section{Stress Increases PDE4 Activity to Enhance cAMP Degradation}

The preceding results point out that the inhibitory effect of stress on mossy fiber LTP may arise from a facilitation of the metabolism of cAMP to AMP and hence to adenosine. As a further test of whether the adenylyl cyclase activity was
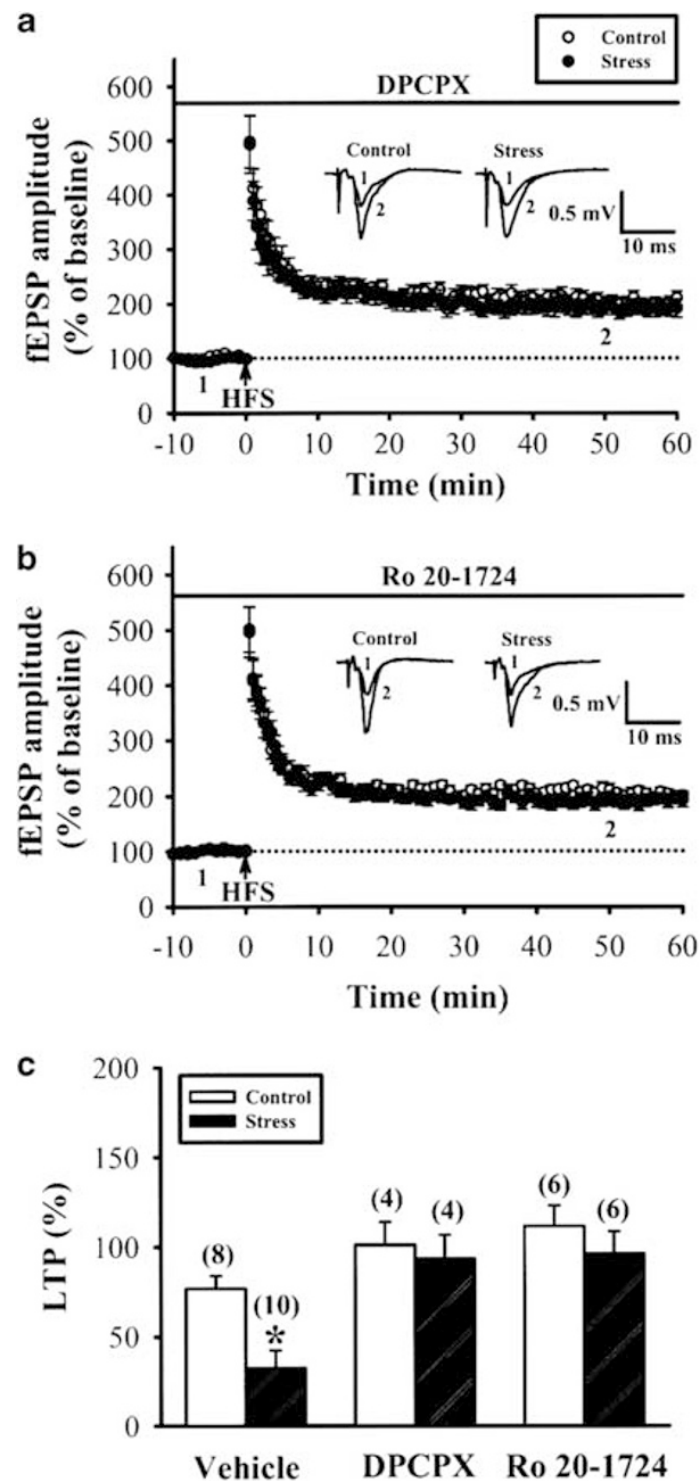

Figure 5 PDE4 signaling mediates the stress-induced impairment of mossy fiber LTP. (a) Summary of experiments shows that the slices from stressed mice displayed a normal HFS-induced LTP $(n=4$; filled symbols) in the presence of the adenosine $A_{\text {I }}$ receptor antagonist DPCPX $(I \mu \mathrm{M})$ when compared with those from control mice $(n=4$; open symbols). (b) Summary of experiments shows that the slices from stressed mice displayed a normal HFS-induced LTP ( $n=6$; filled symbols) in the presence of the PDE4 blocker Ro 20-1724 (200 $\mu \mathrm{M})$ when compared with those from control mice ( $n=6$; open symbols). (c) Summary graph compares the effects of vehicle (0.1\% DMSO), DPCPX, and Ro 20-1724 on the induction of LTP in slices from control and stressed rats. The magnitude of potentiation was measured 50 min after HFS. Data are taken from (a) and (b). HFS was delivered after sufficient stable baseline recordings in the presence of DPCPX or Ro 20-1724. Horizontal bars denote the period of delivery of drugs. The superimposed fEPSPs in the inset illustrate respective recordings from example experiments taken at the time indicated by number. Dash lines show level of baseline. The number in the parenthesis represents the number of animal used. Error bars indicate SEM. $* p<0.05$ compared with control mice using unpaired Student's t-test.

changed after stress, the crude synaptosomal fractions of the hippocampal CA3 region were prepared for forskolinstimulated adenylyl cyclase activity assay. We found that forskolin $(25 \mu \mathrm{M})$-stimulated cAMP production was 


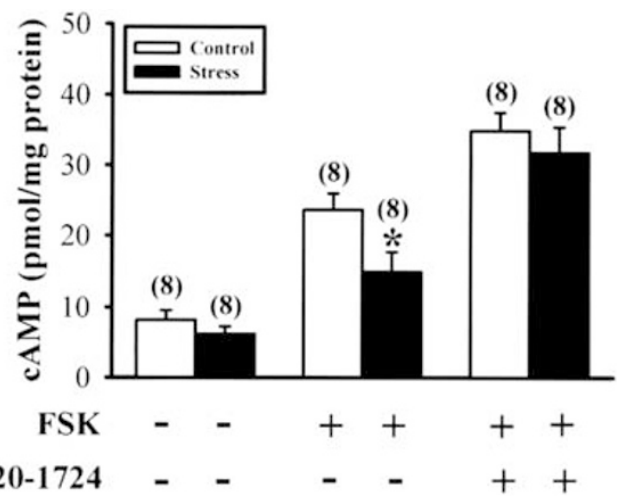

Figure 6 Forskolin-stimulated adenylyl cyclase activities in the hippocampal CA3 synaptosomes from control and stressed mice. A summary bar graph shows that the inhibitory effect of stress on forskolin $(25 \mu \mathrm{M})$ stimulated cAMP production was blocked in the presence of Ro 20- I724 $(200 \mu M)$. The number in the parenthesis represents the number of animal used. Error bars indicate SEM. * $p<0.05$ compared with control mice using unpaired Student's t-test.

markedly reduced in the synaptosomes isolated from stressed mice in the absence of PDE4 inhibitor Ro 201724. However, in the presence of Ro 20-1724 $(200 \mu \mathrm{M})$, the levels of forskolin-stimulated cAMP production showed similar in the synaptosomes isolated from stressed and control mice (Figure 6). These results indicate that stress does not affect adenylyl cyclase activity and that stressinduced decrease in cAMP content is mediated, at least in part, by accelerating cAMP metabolism.

To complement the above pharmacological results, we directly compared the PDE4 activity in the CA3 region of hippocampal slices from stressed and control mice. As shown in Figure 7a, a significant increase in the PDE4 activity was observed in slices from stressed mice when compared with control mice. No significant difference was observed between stressed and control mice in non-PDE4 activity. In addition, the increase in PDE4 activity in stressed mice was prevented when the mice were given glucocorticoid receptor antagonist RU38486 (40 mg/kg) before experiencing stress (Figure 7b). Conversely, prior administration of mineralocorticoid receptor antagonist RU28318 (10 mg/kg) did not affect the enhancement effect of stress on PDE4 activity.

\section{DISCUSSION}

In this study, we have shown that acute behavior stress impairs hippocampal mossy fiber LTP. Our results support an action mode in which stress increases the circulating corticosterone levels, leading to the activation of glucocorticoid receptors, and thereby resulting in enhancing PDE4 activity to accelerate the metabolism of cAMP to adenosine. Adenosine acting on adenosine $\mathrm{A}_{1}$ receptors, therefore, impairs the transmitter release machinery and ultimately counteracts the expression of mossy fiber LTP.

It has been recognized for some time that stressful events increase release of corticosterone from the adrenal glands to interfere the induction of hippocampal long-term synaptic plasticity (McEwen and Sapolsky, 1995; Yang et al, 2004,
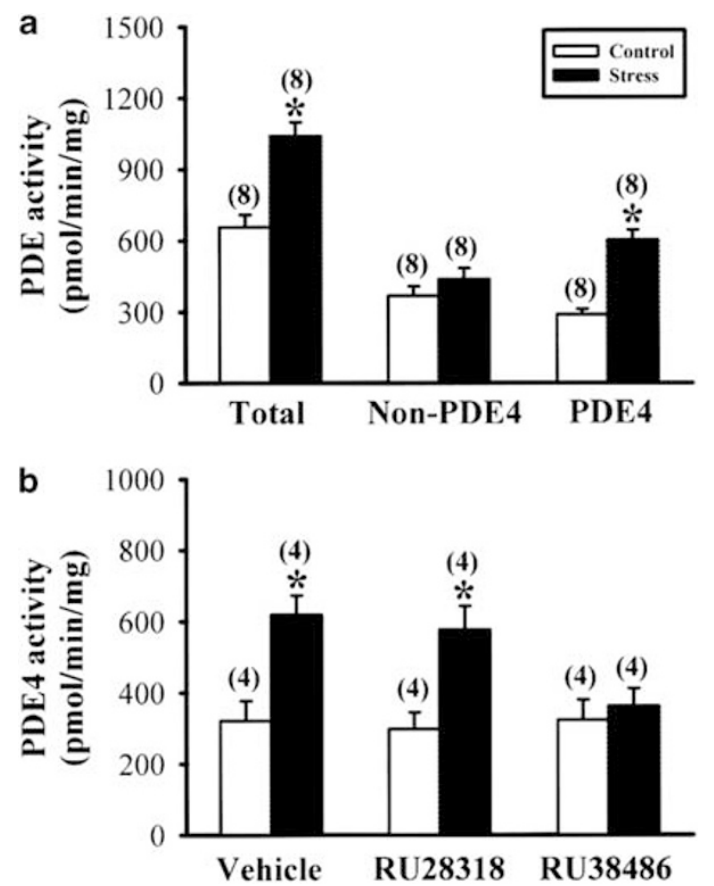

Figure 7 The total PDE, non-PDE4, and PDE4 activities in the hippocampal CA3 slices from control and stressed mice. (a) A summary bar graph shows that stress significantly increased the PDE4 activity, but not non-PDE4 activity. (b) A summary bar graph shows that stress-induced increase in PDE4 activity was specifically blocked by RU38486 (40 mg/kg) administration 30 min before stress exposure. In contrast, prior administration of RU28318 (10 mg/kg) had no effect on the stress-induced increase in PDE4 activity. PDE4 activity was obtained by subtracting the non-PDE4 (ie rolipram-insensitive PDE) activity from the total PDE activity. The number in the parenthesis represents the number of animal used. Error bars indicate SEM. * $p<0.05$ compared with control mice using unpaired Student's t-test.

2006, 2008). In the hippocampal CA1 region, Diamond et al (1992) first reported that the correlation between circulating corticosterone levels and primed burst potentiation more closely resembles an inverted U-shaped curve, that is at high levels of corticosterone $(>20 \mu \mathrm{mol} / \mathrm{dl})$, the correlation was negative, whereas at low levels of corticosterone $(<10 \mu \mathrm{mol} /$ $\mathrm{dl}$ ), the correlation was positive; a peak potentiation was obtained at intermediate levels of corticosterone (11$20 \mu \mathrm{mol} / \mathrm{dl})$. Additional studies have indicated that under conditions in which mineralocorticoid receptors are selectively activated, corticosterone enhances LTP induction, whereas when glucocorticoid receptors are activated, LTP is suppressed (Pavlides et al, 1993; Kerr et al, 1994). These findings suggest that basal levels of corticosterone during the diurnal cycle enhance LTP through stimulation of mineralocorticoid receptors, and during stressful situation, glucocorticoid receptor stimulation becomes important because levels of corticosterone become high to activate this type of receptors (McEwen and Sapolsky, 1995). Our results confirm and extend such findings at the mossy fiberCA3 synapses by showing that glucocorticoid receptor activation mainly mediates the impairment of LTP by acute stress. Furthermore, corticosterone seems to exert its effect on mossy fiber LTP through the activation of classical cytosolic glucocorticoid receptors, as RU38486 pretreatment completely blocks the effect of stress (Figure 3). 
The cAMP is a second messenger in the brain signal transduction system and has been proposed to have a crucial function in the expression of mossy fiber LTP. The mechanisms by which cAMP causes a persistent synaptic potentiation have not been fully defined, but it may be attributable to activate PKA, which then increases glutamate release, probably by modifying the transmitter release machinery in a process requiring Rab3A and RIM1 $\alpha$ (Huang et al, 1994; Weisskopf et al, 1994; Castillo et al, 1997; Nicoll and Schmitz, 2005). In line with this concept, our present work shows that the stress-induced impairment of mossy fiber LTP is at least partially associated with an acceleration of the metabolism of cAMP to adenosine. Three lines of evidence support this conclusion. First, stress-induced impairment of mossy fiber LTP was rescued by the adenosine $\mathrm{A}_{1}$ receptor antagonist DPCPX and the PDE4 inhibitor Ro 20-1724 (Figure 5). Second, the inhibitory effect of stress on forskolin-induced cAMP production in the CA3 synaptosomes was eliminated in the presence of Ro 20-1724 (Figure 6). Third, the basal PDE4 activity of the hippocampal CA3 region was significantly higher in slices from stressed mice than those of control mice (Figure 7). Although an impairment of mossy fiber LTP may result from the deficit in signal transduction components downstream from cAMP that mediate synaptic potentiation, it seems unlikely that this mechanism may account for the stress-induced impairment of LTP. Indeed, we found that the magnitude of Sp-8-bromo-cAMPs-induced LTP was not altered after stress.

The conversion of cAMP to adenosine occurs through a two-step process, in which cAMP is first converted by a PDE to AMP and then to adenosine by $5^{\prime}$-nucleotidase (Latini and Pedata, 2001). The results of this study show that stressinduced decrease in the forskolin-stimulated cAMP production in the synaptosomes was almost completely inhibited by the PDE4 blocker Ro 20-1724. This observation would suggest that stress accelerates the metabolism of cAMP to adenosine by enhancing PDE4 activity. Consistent with our observations, a recent study also reported that sleep deprivation stress significantly increased PDE4 activity in the mouse hippocampus and impaired subsequent LTP induction at the Schaffer collateral-CA1 synapses (Vecsey et al, 2009). The precise mechanism by which stress enhances PDE4 activity remained to be determined. Earlier work from our and other laboratories has shown that acute stress can elicit a sustained activation of the extracellular signal-regulated kinase (ERK)1/2-coupling signaling cascade in the hippocampus (Yang et al, 2004; Shen et al, 2004). Moreover, it has been reported that ERK2 activation can increase the PDE4B isoenzyme activity by direct phosphorylation (Baillie et al, 2000; Mackenzie et al, 2000). Given that PDE4B is highly expressed in the hilus of the mouse-dentate gyrus (Cherry and Davis, 1999), it seems possible that the sustained enhancement of PDE4 activity after stress is involved in an increased ERK2mediated phosphorylation of PDE4B, in turn leading to an activation of this isoenzyme; however, further work involving the use of the specific PDE4B knockout mice is needed to test this hypothesis. Moreover, our results showed that application of the glucocorticoid receptor antagonist RU38486 before stress completely prevented the enhancement effect of stress on PDE4 activity (Figure 7b), indicating that stress increases PDE4 activity by the activation of glucocorticoid receptors. Interestingly, a renal ecto-phosphodiesterase (ecto-PDE) has been proposed to be involved in extracellular metabolism of cAMP to AMP and hence to adenosine by ecto-5'-nucleotidase (Jackson et al, 2007). As these reactions usually occur within a highly localized environment, the newly formed adenosine would then act in an autocrine and/or a paracrine manner to regulate the local response to adenylyl cyclase activation (Jackson et al, 2007). It will be interesting to determine whether PDE4 exerts the effects of stress on mossy fiber LTP through its ecto-PDE activity.

The function of extracellular adenosine in regulating the induction of mossy fiber LTP is still controversial with evidence for both inhibitory (Alzheimer et al, 1991) and stimulatory effects (Moore et al, 2003). In guinea pig hippocampal slices, bath application of adenosine $(50 \mu \mathrm{M})$ has been shown to suppress the induction of mossy fiber LTP (Alzheimer et al, 1991). This finding is in contrast with observations made in an earlier study showing that removal tonic adenosine $A_{1}$ receptor activation by pharmacological or genetic knockout impaired the induction of mossy fiber LTP (Moore et al, 2003). The reason for this discrepancy is unclear, but could be attributable, at least in part, to the different concentrations of adenosine in their preparations or different species of experimental animals, resulting in activation of different cellular processes that may vary in their mode of action. As stress-induced impairment of forskolin- and HFS-induced LTP was antagonized in the presence of DPCPX (Figures 4c and 5a), our data are mostly simply explained by a function for adenosine $A_{1}$ receptor activation in mediating stress effect. How might adenosine $A_{1}$ receptor activation impair the expression of mossy fiber LTP? As the expression of mossy fiber LTP involves a sustained increase in the probability of transmitter release (Zalutsky and Nicoll, 1990; Weisskopf and Nicoll, 1995; Kawamura et al, 2004; Reid et al, 2004), it seems likely that sustained activation of adenosine $A_{1}$ receptors after the LTP induction inhibits transmitter release and thereby counteracts the expression of LTP. In fact, activation of adenosine $A_{1}$ receptors has been reported to suppress synaptic transmission at the hippocampal mossy fiber-CA3 synapses through a mechanism involving presynaptic inhibition of both P/Q- and N-type voltage-dependent $\mathrm{Ca}^{2+}$ channels (Gundlfinger et al, 2007). Our results also show that the basal level of endogenous adenosine and the responsiveness of adenosine $A_{1}$ receptors to adenosine were not changed after stress. This might explain why the basal synaptic transmission, PPF, and frequency facilitation were not affected by acute stress. This is consistent with an earlier report showing that basal transmitter release and shortterm synaptic plasticity at the mossy fiber synapses are under mild control of ambient adenosine (Kukley et al, 2005). Here, we show that removing the inhibitory action of adenosine with a high concentration of DPCPX $\left(1 \mu \mathrm{M} ; K_{\mathrm{d}}\right.$ value of adenosine $A_{1}$ receptor $\sim 1-3 \mathrm{nM}$ ) (Lohse et al, 1987 ) increased mossy fiber fEPSP amplitude by only $20 \%$. This amount of enhancement is in good agreement with an earlier study (Kukley et al, 2005), but is much less than reported by Moore et al (2003), who showed a marked increase $(500 \%)$ in the amplitude of mossy fiber fEPSP during application of DPCPX. The reasons for these 
discrepancies are unclear, but could be attributable to some differences in experimental variables (ie, the type of recording chamber, the composition of aCSF solution and the temperature in the recording).

Our results seem to be in disagreement with the findings of Pavlides et al (2002), who showed that both acute and chronic stress had no influence on the induction of LTP in the mossy fiber input to CA3 hippocampal field. These authors, using a restraint stress paradigm (6h/day), reported that animals subjected to stress displayed comparable LTP to controls, as measured $48 \mathrm{~h}$ after the stress. The discrepancy between this and our findings may be due to the different experimental conditions used (eg, SpragueDawley rats $v s$ C57BL/6 mice, different types of stressor and time of testing). This is supported by the observation that the rise in plasma corticosterone levels in their experiments was significantly lower than those observed in our experiments (twofold $v s$ eightfold). Further studies should clarify this aspect. It seems unlikely that the observed stress-induced impairment of mossy fiber LTP occurred being contaminated by the LTP at the CA3 recurrent collateral synapses, because mossy fiber LTP was induced in the presence of NMDA receptor antagonist D-APV (Bains et al, 1999). However, our findings are consistent with observations made in a recent study, which reported that exposure to acute tail suspension stress attenuated subsequent mossy fiber LTP induction in rats (Takeda et al, 2009). Interestingly, they found that the facilitated zinc influx into the hippocampal cells may be involved in attenuation of mossy fiber LTP observed in the stressed rats. Whether such mechanism may also be relevant to our acute restraint-tail-shock stress model remains to be determined in future studies.

One limitation of our study is that we did not examine whether exposure to acute stress is also capable of blocking the induction of mossy fiber LTP in vivo. In addition, differential sensitivity to stress has long been noted in rodent species (Feder et al, 2009). Additional studies are needed to explore these issues in behaving mice and/or rats.

In conclusion, we have provided evidence that, such as NMDA receptor-dependent LTP observed in the CA1 region and the dentate gyrus, acute stress impairs NMDA receptorindependent mossy fiber LTP. We have further identified and highlighted a crucial function of PDE4 as a novel molecular component underlying the deleterious effect of stress on mossy fiber LTP. To the extent that mossy fiber synaptic plasticity is important for the establishment of hippocampus-dependent associative learning and spatial memory (Mitsuno et al, 1994; Wu et al, 1995; Otto et al, 2001; Gruart et al, 2006), the processes involved in the impairment of mossy fiber LTP may contribute to the development of associative and spatial learning and memory deficits. Our results identify the specific target underlying stress effect and would, therefore, be useful for facilitating the development of new therapeutic strategies leading to prevent stress-induced memory impairments.

\section{ACKNOWLEDGEMENTS}

This work was supported by research grants from the National Science Council (NSC97-2321-B-006-008) and the
National Health Research Institute (NHRI-EX98-9618NI), Taiwan, ROC.

\section{DISCLOSURE}

The authors declare no conflict of interest. The authors affirm that there are no financial, personal, or other relationships with other people or organizations that have inappropriately influenced or biased their work.

\section{REFERENCES}

Ahmed T, Frey JU, Korz V (2006). Long-term effects of brief acute stress on cellular signaling and hippocampal LTP. J Neurosci 26: 3951-3958.

Alzheimer C, Röhrenbeck J, ten Bruggencate G (1991). Adenosine depresses induction of LTP at the mossy fiber-CA3 synapse in vitro. Brain Res 543: 163-165.

Baillie GS, MacKenzie SJ, McPhee I, Houslay MD (2000). Subfamily selective actions in the ability of Erk2 MAP kinase to phosphorylate and regulate the activity of PDE4 cyclic AMPspecific phosphodiesterases. Br J Pharmacol 131: 811-819.

Bains JS, Longacher JM, Staley KJ (1999). Reciprocal interactions between CA3 network activity and strength of recurrent collateral synapses. Nat Neurosci 2: 720-726.

Bruns RF, Lu GH, Pugsley TA (1986). Characterization of the $A_{2}$ adenosine receptor labeled by $\left[{ }^{3} \mathrm{H}\right] \mathrm{NECA}$ in rat striatal membranes. Mol Pharmacol 29: 331-346.

Castillo PE, Janz R, Südhof TC, Tzounopoulos T, Malenka RC, Nicoll RA (1997). Rab3A is essential for mossy fibre long-term potentiation in the hippocampus. Nature 388: 590-593.

Chen YL, Huang CC, Hsu KS (2001). Time-dependent reversal of long-term potentiation by low-frequency stimulation at the hippocampal mossy fiber-CA3 synapses. J Neurosci 21: 3705-3714.

Cherry JA, Davis RL (1999). Cyclic AMP phosphodiesterases are localized in regions of the mouse brain associated with reinforcement, movement, and affect. J Comp Neurol 407: 287-301.

Coffin VL, Spealman RD (1989). Psychomotor-stimulant effects of 3-isobutyl-1-methylxanthine: comparison with caffeine and 7-(2-chloroethyl) theophylline. Eur J Pharmacol 170: $35-40$.

Diamond DM, Bennett MC, Fleshner M, Rose GM (1992). Inverted$\mathrm{U}$ relationship between the level of peripheral corticosterone and the magnitude of hippocampal primed burst potentiation. Hippocampus 2: 421-430.

Diamond DM, Park CR, Campbell AM, Woodson JC (2004). Competitive interactions between endogenous LTD and LTP in the hippocampus underlie the storage of emotional memories and stress-induced amnesia. Hippocampus 15: 1006-1025.

Feder A, Nestler EJ, Charney DS (2009). Psychobiology and molecular genetics of resilience. Nat Rev Neurosci 10: 446-457.

Fredholm BB, Dunwiddie TV (1988). How does adenosine inhibit transmitter release? Trends Pharmacol Sci 9: 130-134.

Garcia R (2001). Stress, hippocampal plasticity, and spatial learning. Synapse 40: 180-183.

Griffith WH (1990). Voltage-clamp analysis of posttetanic potentiation of the mossy fiber to CA3 synapse in hippocampus. J Neurophysiol 63: 491-501.

Gruart A, Muñoz MD, Delgado-García JM (2006). Involvement of the CA3-CA1 synapse in the acquisition of associative learning in behaving mice. J Neurosci 26: 1077-1087.

Gundlfinger A, Bischofberger J, Johenning FW, Torvinen M, Schmitz D, Breustedt J (2007). Adenosine modulates transmission at the hippocampal mossy fibre synapse via 
direct inhibition of presynaptic calcium channels. J Physiol 582: 263-277.

Harris EW, Cotman CW (1986). Long-term potentiation of guinea pig mossy fiber responses is not blocked by N-methyl Daspartate antagonists. Neurosci Lett 70: 132-137.

Huang CC, Chen YL, Liang YC, Hsu KS (2002). Role for cAMP and protein phosphatase in the presynaptic expression of mouse hippocampal mossy fibre depotentiation. J Physiol 543: 767-778.

Huang CC, Yang CH, Hsu KS (2005). Do stress and long-term potentiation share the same molecular mechanisms? Mol Neurobiol 32: 223-235.

Huang YY, Li XC, Kandel ER (1994). cAMP contributes to mossy fiber LTP by initiating both a covalently mediated early phase and macromolecular synthesis-dependent late phase. Cell 79: 69-79.

Jackson EK, Ren J, Zacharia LC, Mi Z (2007). Characterization of renal ecto-phosphodiesterase. J Pharmacol Exp Ther 321: 810-815.

Jacobson L, Sapolsky R (1991). The role of the hippocampus in feedback regulation of the hypothalamic-pituitary-adrenocortical axis. Endocr Rev 12: 118-134.

Kavushansky A, Vouimba RM, Cohen H, Richter-Levin G (2006). Activity and plasticity in the CA1, the dentate gyrus, and the amygdala following controllable vs uncontrollable water stress. Hippocampus 16: 35-42.

Kawamura Y, Manita S, Nakamura T, Inoue M, Kudo Y, Miyakawa $\mathrm{H}$ (2004). Glutamate release increases during mossy-CA3 LTP but not during Schaffer-CA1 LTP. Eur J Neurosci 19: 1591-1600.

Kerr DS, Huggett AM, Abraham WC (1994). Modulation of hippocampal long-term potentiation and long-term depression by corticosteroid receptor activation. Psychobiology 22: 123-133.

Kim JJ, Diamond DM (2002). The stressed hippocampus, synaptic plasticity and lost memories. Nat Rev Neurosci 3: 453-462.

Kim JJ, Foy MR, Thompson RF (1996). Behavioral stress modifies hippocampal plasticity through N-methyl-D-aspartate receptor activation. Proc Natl Acad Sci USA 93: 4750-4753.

Kim JJ, Yoon KS (1998). Stress: metaplastic effects in the hippocampus. Trends Neurosci 21: 505-509.

Kim PJ, Cole MA, Kalman BA, Spencer RL (1998). Evaluation of RU28318 and RU40555 as selective mineralocorticoid receptor and glucocorticoid receptor antagonists, respectively: receptor measures and functional studies. J Steroid Biochem Mol Biol 67: 213-222.

Korz V, Frey JU (2003). Stress-related modulation of hippocampal long-term potentiation in rats: involvement of adrenal steroid receptors. J Neurosci 23: 7281-7287.

Korz V, Frey JU (2005). Bidirectional modulation of hippocampal long-term potentiation under stress and no-stress conditions in basolateral amygdala-lesioned and intact rats. J Neurosci 25: 7393-7400.

Kukley M, Schwan M, Fredholm BB, Dietrich D (2005). The role of extracellular adenosine in regulating mossy fiber synaptic plasticity. J Neurosci 25: 2832-2837.

Latini S, Pedata F (2001). Adenosine in the central nervous system: release mechanisms and extracellular concentrations. J Neurochem 79: 463-484.

Lohse MJ, Klotz KN, Lindenborn-Fotinos J, Reddington M, Schwabe U, Olsson RA (1987). 8-Cyclopentyl-1,3-dipropylxanthine (DPCPX)-a selective high affinity antagonist radioligand for $\mathrm{A}_{1}$ adenosine receptors. Naunyn Schmiedebergs Arch Pharmacol 336: 204-210.

Lu KT, Gean PW (1999). Masking of forskolin-induced long-term potentiation by adenosine accumulation in area CA1 of the rat hippocampus. Neuroscience 88: 69-78.

MacKenzie SJ, Baillie GS, McPhee I, Bolger GB, Houslay MD (2000). ERK2 mitogen-activated protein kinase binding, phosphorylation, and regulation of the PDE4D cAMP-specific phosphodiesterases. The involvement of $\mathrm{COOH}$-terminal docking sites and NH2-terminal UCR regions. J Biol Chem 275: 16609-16617.

McEwen BS (1999). Stress and hippocampal plasticity. Annu Rev Neurosci 22: 105-122.

McEwen BS, Sapolsky RM (1995). Stress and cognitive function. Curr Opin Neurobiol 5: 205-216.

McPhee I, Cochran S, Houslay MD (2001). The novel long PDE4A10 cyclic AMP phosphodiesterase shows a pattern of expression within brain that is distinct from the long PDE4A5 and short PDE4A1 isoforms. Cell Signal 13: 911-918.

Moore KA, Nicoll RA, Schmitz D (2003). Adenosine gates synaptic plasticity at hippocampal mossy fiber synapses. Proc Natl Acad Sci USA 100: 14397-14402.

Mitsuno K, Sasa M, Ishihara K, Ishikawa M, Kikuchi H (1994). LTP of mossy fiber-stimulated potentials in CA3 during learning in rats. Physiol Behav 55: 633-638.

Nicoll RA, Malenka RC (1995). Contrasting properties of two forms of long-term potentiation in the hippocampus. Nature 377: 115-118.

Nicoll RA, Schmitz D (2005). Synaptic plasticity at hippocampal mossy fibre synapses. Nat Rev Neurosci 6: 863-876.

Ortiz J, Harris HW, Guitart X, Terwilliger RZ, Haycock JW, Nestler EJ (1995). Extracellular signal-regulated protein kinases (ERKs) and ERK kinase (MEK) in brain: regional distribution and regulation by chronic morphine. J Neurosci 15: 1285-1297.

Otto C, Kovalchuk Y, Wolfer DP, Gass P, Martin M, Zuschratter W et al (2001). Impairment of mossy fiber long-term potentiation and associative learning in pituitary adenylate cyclase activating polypeptide type I receptor-deficient mice. J Neurosci 21: 5520-5527.

Pavlides C, Nivón LG, McEwen BS (2002). Effects of chronic stress on hippocampal long-term potentiation. Hippocampus 12: 245-257.

Pavlides C, Watanabe Y, McEwen BS (1993). Effects of glucocorticoids on hippocampal long-term potentiation. Hippocampus 3: 183-192.

Reid CA, Dixon DB, Takahashi M, Bliss TV, Fine A (2004). Optical quantal analysis indicates that long-term potentiation at single hippocampal mossy fiber synapses is expressed through increased release probability, recruitment of new release sites, and activation of silent synapses. J Neurosci 24: 3618-3626.

Roozendaal B, McEwen BS, Chattarji S (2009). Stress, memory and the amygdala. Nat Rev Neurosci 10: 423-433.

Saal D, Dong Y, Bonci A, Malenka RC (2003). Drugs of abuse and stress trigger a common synaptic adaptation in dopamine neurons. Neuron 37: 577-582.

Salin PA, Scanziani M, Malenka RC, Nicoll RA (1996). Distinct short-term plasticity at two excitatory synapses in the hippocampus. Proc Natl Acad Sci USA 93: 13304-13309.

Seligman ME, Maier SF (1967). Failure to escape traumatic shock. J Exp Psychol 74: 1-9.

Shen CP, Tsimberg Y, Salvadore C, Meller E (2004). Activation of ERK and JNK MAPK pathways by acute swim stress in rat brain regions. BMC Neurosci 5: 36.

Shors TJ, Dryver E (1994). Effect of stress and long-term potentiation (LTP) on subsequent LTP and the theta burst response in the dentate gyrus. Brain Res 666: 232-238.

Shors TJ, Foy MR, Levine S, Thompson RF (1989). Unpredictable and uncontrollable stress impairs neuronal plasticity in the rat hippocampus. Brain Res Bull 24: 663-667.

Südhof TC (2004). The synaptic vesicle cycle. Annu Rev Neurosci 27: $509-547$.

Takeda A, Ando M, Kanno S, Oku N (2009). Unique response of zinc in the hippocampus to behavioral stress and attenuation of subsequent mossy fiber long-term potentiation. Neurotoxicology 30: $712-717$. 
Tzounopoulos T, Janz R, Südhof TC, Nicoll RA, Malenka RC (1998). A role for cAMP in long-term depression at hippocampal mossy fiber synapses. Neuron 21: 837-845.

Vecsey CG, Baillie GS, Jaganath D, Havekes R, Daniels A, Wimmer $\mathrm{M}$ et al (2009). Sleep deprivation impairs cAMP signalling in the hippocampus. Nature 461: 1122-1125.

Weisskopf MG, Castillo PE, Zalutsky RA, Nicoll RA (1994). Mediation of hippocampal mossy fiber long-term potentiation by cyclic AMP. Science 265: 1878-1882.

Weisskopf MG, Nicoll RA (1995). Presynaptic changes during mossy fibre LTP revealed by NMDA receptor-mediated synaptic responses. Nature 376: 256-259.

Wu ZL, Thomas SA, Villacres EC, Xia Z, Simmons ML, Chavkin C et al (1995). Altered behavior and long-term potentiation in type I adenylyl cyclase mutant mice. Proc Natl Acad Sci USA 92: 220-224.

Xu L, Anwyl R, Rowan MJ (1997). Behavioural stress facilitates the induction of long-term depression in the hippocampus. Nature 387: 497-500.

Yang CH, Huang CC, Hsu KS (2004). Behavioral stress modifies hippocampal synaptic plasticity through corticosterone-induced sustained extracellular signal-regulated kinase/mitogen-activated protein kinase activation. J Neurosci 24: 11029-11034.

Yang CH, Huang CC, Hsu KS (2005). Behavioral stress enhances hippocampal CA1 long-term depression through the blockade of the glutamate uptake. J Neurosci 25: 4288-4293.

Yang CH, Huang CC, Hsu KS (2006). Novelty exploration elicits a reversal of acute stress-induced modulation of hippocampal synaptic plasticity in the rat. J Physiol 577: 601-615.

Yang PC, Yang CH, Huang CC, Hsu KS (2008). Phosphatidylinositol 3kinase activation is required for stress protocol-induced modification of hippocampal synaptic plasticity. J Biol Chem 283: 2631-2643.

Yuen EY, Liu W, Karatsoreos IN, Feng J, McEwen BS, Yan Z (2009). Acute stress enhances glutamatergic transmission in prefrontal cortex and facilitates working memory. Proc Natl Acad Sci USA 106: 14075-14079.

Zalutsky RA, Nicoll RA (1990). Comparison of two forms of long-term potentiation in single hippocampal neurons. Science 248: 1619-1624.

Zucker RS (1989). Short-term synaptic plasticity. Annu Rev Neurosci 12: 13-31.

Zucker RS, Regehr WG (2002). Short-term synaptic plasticity. Annu Rev Physiol 64: 355-405.

Supplementary Information accompanies the paper on the Neuropsychopharmacology website (http://www.nature.com/npp) 